University of Louisville

ThinkIR: The University of Louisville's Institutional Repository

Electronic Theses and Dissertations

8-2021

\title{
Witness and testimony: the role of race and community in forming Black Aesthetics.
}

Cathy Smith Shannon

University of Louisville

Follow this and additional works at: https://ir.library.louisville.edu/etd

Part of the Art and Design Commons

\section{Recommended Citation}

Shannon, Cathy Smith, "Witness and testimony: the role of race and community in forming Black Aesthetics." (2021). Electronic Theses and Dissertations. Paper 3650.

https://doi.org/10.18297/etd/3650

This Master's Thesis is brought to you for free and open access by ThinkIR: The University of Louisville's Institutional Repository. It has been accepted for inclusion in Electronic Theses and Dissertations by an authorized administrator of ThinkIR: The University of Louisville's Institutional Repository. This title appears here courtesy of the author, who has retained all other copyrights. For more information, please contact thinkir@louisville.edu. 


\title{
WITNESS AND TESTIMONY: THE ROLE OF RACE AND COMMUNITY IN FORMING BLACK AESTHETICS
}

\author{
By \\ Cathy Smith Shannon \\ B.A. University of Louisville, 1984 \\ M.A., University of Louisville, 2021 \\ A Thesis \\ Submitted to the Faculty of the \\ College of Arts and Sciences of the University of Louisville \\ In Partial Fulfillment of the Requirements \\ For the Degree of \\ Master of Arts \\ In Art (c) and Art History: \\ Concentration in Critical and \\ Curatorial Studies \\ Department of Fine Arts \\ University of Louisville \\ Louisville, Kentucky
}

May 2021 


\section{Copyright 2021 by Cathy Smith Shannon}

All rights reserved 



\title{
WITNESS AND TESTIMONY: THE ROLE OF RACE \\ AND COMMUNITY IN FORMING BLACK AESTHETICS
}

\author{
By \\ Cathy Smith Shannon \\ B.A. University of Louisville, 1984 \\ M.A., University of Louisville, 2021
}

Thesis Approved on

April 29, 2021

By the following Thesis Committee:

Christopher Reitz

Jill Holaday

Andrea Olinger 


\section{DEDICATION}

This thesis is dedicated to my parents

Mr. Willie Lee Smith, for always believing in me

and

Mrs. Frances Mae Dawson Smith, for showing me strength and unconditional love 


\section{ACKNOWLEDGMENTS}

I wish to thank all of my professors for their patience, guidance, and encouragement especially my Advisor, Dr. Christopher Reitz, for challenging me and Professor Ying Chan for his immersive introduction to Graduate School and insightful museum tour of New York City museums reinforced my decision to pursue my Master of Arts in Critical and Curatorial studies. I also want to thank my sisters, Katrina Smith Gilbert and Leslie M. Smith, for always encouraging me. Finally, all of my love and gratitude goes to my partner, best friend, and loving husband Walter B. Shannon, Jr., without whom I may never have been on the path that I am today. 


\section{ABSTRACT \\ WITNESS AND TESTIMONY: THE ROLE OF RACE AND COMMUNITY IN FORMING BLACK AESTHETICS \\ Cathy Smith Shannon}

May 7, 2021

This thesis is a visual examination of the relationship of community to output of black artists, inspired by the Social Justice movement of 2020. It was important to note the impact on artistic output of community and environment that influenced each artist. This thesis looks at the work of two artists that grew up in the 1930s and launched their This thesis looks at the work of two artists that grew up in the 1930s and launched their Rights era of the 1960s began their artistic careers during the 1980s; and two artist that were born during the 1960s Civil rights era, and began their artistic journey in the 1990s and 2000s.

Rather than simply speak to their aesthetic, this thesis and the ensuing exhibition seeks to look investigate how the communities in which each artist grew, informed, and influenced how they approached and responded to the events of 2020 that lead to the social justice protest of 2021, as well as how artist responded in the past to injustices and misrepresentation of black in America. This thesis will serve as the catalog for the exhibition of the works referenced for the public to the visual exhibition of the collective approach of six artists from different communities and periods, using different media. 
TABLE OF CONTENTS

PAGE

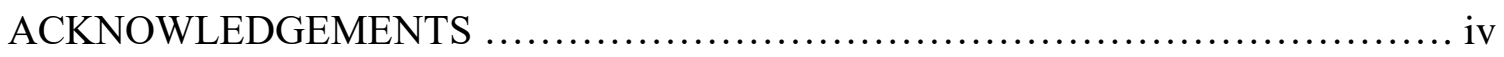

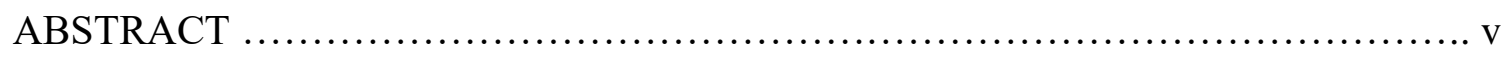

THE ROLE OF RACE AND COMMUNITY $\ldots \ldots \ldots \ldots \ldots \ldots \ldots \ldots \ldots \ldots \ldots \ldots \ldots \ldots \ldots$

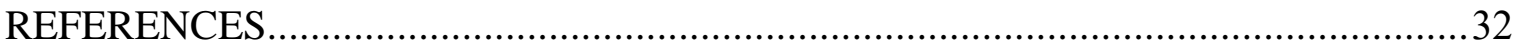

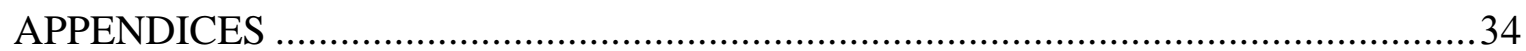

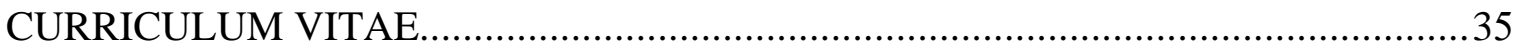




\begin{tabular}{|c|c|c|c|}
\hline Mother and Child & $\begin{array}{l}\text { S } \\
\text { I Have Special Reservations }\end{array}$ & 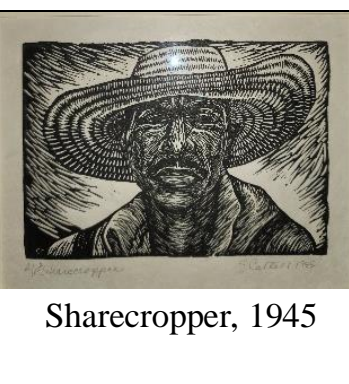 & Sharecropper, 1970 \\
\hline $\begin{array}{l}3 \\
1 \\
1\end{array}$ & Two Rebels & Brotherhood for Peace & Now Is The Time \\
\hline $\begin{array}{c}\text { Back } \\
\text { We've Got Your } \\
\text { Bas }\end{array}$ & Black Love Series & $\begin{array}{l}\text { ches } \\
\text { The Journey Continues } \\
\text { Together - } 75\end{array}$ & $\frac{\text { Afternoon Stroll }}{\underbrace{}_{2}}$ \\
\hline $\begin{array}{c}\text { We Have } \\
\text { Always Been } \\
\text { Royal }\end{array}$ & $\begin{array}{l}\text { Pe } \\
\text { The People in the Field, } \# 4\end{array}$ & Proud Beauty & Zuri, Beautiful \\
\hline Okora, Man & Stolen Queen & $y^{2}$ & 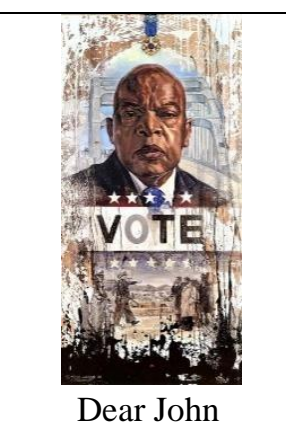 \\
\hline
\end{tabular}




\section{THE ROLE OF RACE AND COMMUNITY}

In 2020, America witnessed the murder of George Floyd at the hands of the police. This act itself was not new to black Americans who have witnessed, buried loved ones, protested against racism, and pleaded for justice for decades. But it was novel for non-black Americans because it was part of a growing number of murders by police caught on camera and shared on social media and news outlets. An individual with a camera acted as a witness, social media bore the testimony and the world was able to see through our eyes and feel what we have always felt. White mothers felt our pain, white fathers felt our anger, and white youth felt our rage. Not long after the videos' release, the world reacted with shock and outrage and soon people across the globe joined tens of thousands of Americans to protest, united by pain, anger, and resolve to end the pandemic of racism that had allowed the murder of innocent blacks for centuries. Citizens filled the streets and black artists, once again started to fill their canvasses to serve as witnesses and to give testimony to yet another heinous act against a black person in America.

Witness and Testimony is not merely another exhibition of art by black artists. The events of 2020 require - indeed they mandate something more. This features the works of black artists from the renowned to the rising, from the self-taught to the formally trained, male and female, working in a variety of media as has been presented over the years since David Driskel's groundbreaking 1976 exhibition Two Centuries of Black American Art annihilated the notion of black art as not worthy of a major museum exhibition. This exhibition does not cover the study of black artists by either of the typical methodological approaches initially utilized by museums and curators; anthropological approach or 
corrective narrative. The former reflects a curiosity concerning the presence of racial otherness coupled with a desire to perpetuate the superiority of mainstream white culture through its contrast with inherently inferior black culture, while the latter was formed out of the necessity to present the art of African American and correct for its historical absence and misrepresentation in mainstream art museums. ${ }^{1}$ The intention of Witness and Testimony is to investigate and explore the language of black artists as informed by the communities that nurtured and encouraged them, or not. It also seeks to show that the circumstances that fueled the social justice protest and caused contemporary artists to bear witness and give testimony to this time were very much present since the era of Jim Crow.

Finally, the artists featured were selected because each has a different artistic voice that was informed by the circumstances of their experiences and the period in which they lived. Elizabeth Catlett and Jacob Lawrence created art during the Jim Crow era of the 1930s and 1940s with Catlett being in Washington DC's HBCU environment and Jacob Lawrence being in the Harlem community. The images featured by each speak to the social injustices of their time and the humanity of people. Both artists achieved national recognition and great distinction during a period when major art institutions and the general public ignored black artists.

\footnotetext{
${ }^{1}$ Bridget R. Crooks, Exhibiting Blackness: African Americans and the American Art Museum (Amherst, MA: University of Massachusetts Press, 2011), 2.
} 
Leroy Campbell and Woodrow Nash both came of age during the Civil Rights era of the 1950s and 1960s and their aesthetic approach was informed by the communities in which they lived and how they experienced life. Campbell was in the segregated South but thrived in the Gullah community of Charleston, SC because of his father's strong influence and insistence that they know who they are and from where they came. Nash came of age during the same period but in the heart of the industrial Midwest of Akron, OH. Campbell is self-taught and thrived when he moved to Brooklyn, NY engulfed by an encouraging community of black artists and supportive art patrons. Nash received formal artistic training and also moved to New York City, but he worked as a professional artist and illustrator in creative and corporate environments that were more restrictive and less diverse. Sherry Shine and Kevin A. Williams both came of age artistically in the post-Civil Rights era of the late 1970s and early 1980s, Shine in New York and Williams in Chicago. A commonality of the contemporary artist is the access that they had to a population that was educated and able to support their artistic endeavors. As a result, each has been able to bypass the New York gallery representation that typically leads to museum curators and earn a living as successful artists. Witness \& Testimony seeks to present fresh voices and approaches that have not been featured in major exhibitions next to the work of those artists who have. Each artist in the exhibit is concerned with creating art that speaks to the people in the communities that informed their aesthetic.

Just as camera phones and social media offered witness and testimony to the pain inflicted on George Floyd, Eric Garner, and others, black artists in America have long played a similar role, sharing black life in America and providing testimony to the 
triumphs and challenges of living while black over the decades. Throughout the more than 400-year history in this country, blacks have shared one consistent desire to be seen, recognized, and treated as human beings. The exhibit begins by reflecting on the black and white images created by Elizabeth Catlett during the Jim Crow era and black and white images by Jacob Lawrence from the Civil Rights era. Moving to contemporary artists the exhibition presents a collection of original works, from oil paintings, to canvas collage, to quilting to consider the diverse themes and media selected and the community influence that informed each artists' aesthetic. The contemporary artists in this exhibition were also selected because of their success within the black retail art market which is further evidence that they have effectively flown under the radar of traditional art institutions to reach the homes and hearts of black people and it can all be attributed to one common goal: their desire to show the humanity of black people. This success can be attributed to one common goal; their desire to show the humanity of black people, bear witness to the challenges faced and give testimony to the triumphs of blackness in America.

The necessity of black artists to serve as historians and caretakers of black culture, documenting black life in America as a result of white America's refusal to do so. Some blacks were encouraged and educated by parents while others learned black history from community sources such as in the case of Jacob Lawrence, discussions at the $135^{\text {th }}$ Street Library (Harlem). ${ }^{2}$ But even as the 1960s ushered in Civil Rights, and the 1970s

\footnotetext{
${ }^{2}$ Romar Bearden and Harry Henderson. A History of African-American Art: From 1792 to Present, (New York: Random House, 1993), 296.
} 
brought in the short-lived era of Affirmative Action there was still misinformation or outright omission regarding black experience in America. When white America would not listen to, let alone talk about the black experience, black artists did, and they continue to do so today. Some of these artists faced discriminatory practices that denied them access to formal training and subjected them to unjust treatment in their artistic careers. Black artists have had to be resilient in the face of racist policies. Thanks to the support and nurturing of black communities and institutions, some artists excelled in their fields and succeeded in telling our stories as was the case with our first artist, Elizabeth Catlett.

\section{Elizabeth Catlett - (1915 - 2012)}

Artist, educator, printmaker whose work documented injustice and showed the humanity of black people when America viewed them as less-than.

It is impossible to have an exhibition about protest art without the work of Elizabeth Catlett. Using her artistic platform, Catlett created art that portrayed black people with dignity and strength as early as 1939 while she was just a Master's student at the University of Iowa while working under Grant Wood. For her thesis, Catlett created Mother and Child, (Figure 1) a 35"h limestone sculpture depicting a black mother holding her baby, which won first prize in the 1940 American Negro Exposition, in Chicago. This sculpture of a mother holding her child challenged the notion of people of color as inferior and weak because she positioned the mother as a strong figure, sitting erect with her head high as she protectively holds her child on her lap. Bold images, powerful sculptures, and poignant declarations were signature elements of Catlett's aesthetic. 
Through her art, Catlett was an unapologetic voice against racism and an outspoken advocate for the marginalization of people of color in the United States and Mexico beginning when she was a college professor at Dillard in New Orleans in the early 1940s. She created a stir by busing her students to a Picasso exhibition at the Delgado Museum of Art (now the Museum of Art of New Orleans), whose only entrance was through a park closed to blacks; she had the students enter the Museum directly from the bus. ${ }^{3}$ (Gouma-Peterson, 1983). Throughout the politically charged, anti-communist McCarthy era of 1940's and throughout her career, Catlett spoke out against injustice even when she could have been arrested (as she often was), or worse.

Born April 15, 1915, in Washington DC, Catlett was the youngest of three children of John and Mary Catlett, who were both educators. Shortly after she was born, her father died and Catlett's mother worked as a dressmaker to support the family. Catlett was a talented student, and she was accepted to the Carnegie Institute of Technology (Carnegie Mellon University) in 1933. However, the school rescinded her scholarship when they discovered, upon her arrival for classes, that she was black. "Friends and family members told me not to apply because they (Carnegie) would not admit a black, but I did it anyway because that practice was wrong" (Catlett, 2008) That rejection, and her mother's encouragement for her to attend Howard University instead, fueled her determination to prove her talent, call out racism through her art, and to challenge injustice whenever she witnessed it taking place. Catlett's sculptures were not demure but rather defiant in the face of the government-sponsored racism that was permitted against

\footnotetext{
${ }^{3}$ Thalia Gouma-Peterson, "Elizabeth Catlett: The Power of Human Feeling and of Art," Woman's Art Journal, no. 1 (1983): 49.
} 
people of color. Catlett was raised by a mother that encouraged her children to succeed and instilled in them a sense of self-worth. Catlett witnessed strength in her mother, received validation of her talent from her black professors at Howard, but she credits Iowa State professor and artist Grant Wood for encouraging her to sculpt. Catlett became the first person at Iowa State to receive an MFA.

One of Catlett's pieces included in this exhibition is I Have Special Reservations (1948) (Figure 2). It depicts an older black woman resolutely seated in the area designated "colored only" on a public bus. She looks steely ahead, her forehead is deeply etched with age lines, her brows are furrowed and dark circles are under her eyes. She is a woman who has worked all of her life and is most likely leaving a job now. This image gives testimony to the injustice suffered by blacks in America under Jim Crow as this woman is made to observe her 'place' in white society. Catlett makes the viewer a witness to this injustice. Many will look at the image and immediately think it is an image depicting Rosa Parks' refusal to give up her seat on that Montgomery bus. But one need only check the date to know that this image precedes Rosa Parks' action by nearly a decade. We may never know if this very image inspired Rosa Parks to move from the role of witness to catalyst for change, but it is important to include it here to document the racial discrimination that was allowed and encouraged.

Still utilizing the woodcut technique, Catlett created her Sharecropper pieces, Sharecropper Male (1945) (Figure 3) and Sharecropper Female (1970) (Figure 4). The earlier male image directly engages the viewer as if demanding to be seen while the 
1970s version looks off as if acknowledging a loved one or another worker. She does the acknowledging, bearing witness, seeing the actions and the struggles. It is this version that is the most widely recognizable and most sought after of Catlett's prints. It was important to Catlett to not only create works that represented black people but to capture the humanity of blacks; not depict them as passive but rather strong, proud, and selfaware. "Art is important only to the extent that it helps in the liberation of our people. It is necessary only at this moment as an aid to our survival." ${ }^{\circ}$ Catlett wore many hats; from artist to agitator, sculptor to educator and printmaker.

It is in her role as a printmaker that Catlett once again broke with industry norms with her decision to produce woodcuts, lithographs, and serigraphs. Catlett looked beyond the concept of prints as a secondary art form because "I wanted my art to be accessible to the people I represented in my art and not to simply have it shut away into museums that had no interest in our imagery, so I made art featuring people of color that they could have access to." (Catlett, 2008). That sentiment was shared by James Lesesne Well, award-winning artist, printmaker, and art professor at Howard University in the 1920s and 1930s, and the 1930s was when Elizabeth Catlett was enrolled at Howard and majoring in art. "Wells made a decision to specialize in printmaking at a time when prints were virtually ignored because he felt they were something that would provide more blacks with the opportunity to own important works by black artists." black artists who were not fortunate enough to receive museum exhibits or gallery representation a way to make an earnest living. The following Catlett images are featured:

\footnotetext{
${ }^{4}$ Gouma-Peterson, "Elizabeth Catlett," 48.

${ }^{5}$ Bearden and Henderson, A History of African American Artist, 393.
} 
I Have Special Reservations (1947) woodcut

Sharecropper (1945) woodcut, male

Sharecropper (1970) lithograph, female

\section{Jacob Lawrence (1917 - 2000)}

His historical narratives document the fight for equality and the triumphs of black people against tyranny that ultimately enabled America to broaden its borders. Jacob Lawrence was born in Atlantic City, NJ in 1917 to working-class parents who moved around and eventually separated when Lawrence was an adolescent. His mother eventually moved to Harlem, NY. There young Jacob would grow to become one of the world's most renowned artists, celebrated for his historical narrative paintings that depicted black people including key figures like Harriett Tubman, John Brown, and General Toussaint L'Ouverture. Lawrence learned the stories of these great leaders from the street orators that captivated Lawrence and held his attention as they presented their historical accounts of these leaders. The Harlem community provided Jacob Lawrence with rich stories and important historical information that he was compelled to capture in art.

Having been raised by a single mother in Harlem after his parents divorced, Lawrence was forced to quit school to help provide income for his family. Lawrence had a deep respect for, and admiration of black men in the community whom he saw working to support their families and their communities as reflected throughout his career with his "Builders" images. Lawrence's mother enrolled in an after-school art program at the $135^{\text {th }}$ Street branch of the public library as a way of keeping thirteen-year-old Jacob from 
falling in with the wrong crowd. Jacob's talent was recognized early on, and he was praised by his art teachers, one of whom was a young Charles Alston. "Whatever Lawrence did, Alston praised, and simply encouraged Lawrence to try to have fun with the available materials which included crayons, pastels, and pencils, for drawing." Alston recognized Lawrence's talent and thought that Lawrence was a very gifted student. Lawrence gained acclaim for his composition, subject matter, and use of colors as he documented the presence, contributions, and historical significance of black people during a period in American history when it was widely accepted to deny their humanity and ignore their existence.

In 1935, having dropped out of high school at the age of 17, Lawrence was inspired by one of his former teachers to attend an exhibition at the Museum of Modern Art (MoMA) of West African sculpture. Prior to attending the exhibit at MoMA, Lawrence's art consisted of street scenes and rarely included people. "The show made a great impression on me, and particularly demonstrated that black people were capable of significant art and were in themselves suitable subjects for such art." That is the point where Lawrence began to focus on people in his art; emphasizing the humanity in the faces gathered around the legs of a street corner orator, in the sick and injured waiting in the Harlem Hospital clinic, in the men seeking work, in step sitters, and neighborhood scenes."7 Beginning in the late 1930s, Lawrence achieved a level of acclaim very few black artists of earlier periods were able to enjoy when his Migration of the Negro series

\footnotetext{
${ }^{6}$ Bearden and Henderson, A History of African American Artists, 294.

${ }^{7}$ Bearden and Henderson, A History of African American Artists, 296.
} 
was shown at the Downtown Gallery in November 1941 and at twenty-four, he became one of the first black artists to be represented by a major New York gallery. ${ }^{8}$

Aside from his historical narratives, the art of Jacob Lawrence reflects the community in which he lived, the streets of Harlem and its residents. His street scenes, like his historical narratives, offer a thoughtful artistic counter to the racist caricatures preferred by the white art establishment during the early part of the $20^{\text {th }}$ century. Lawrence, like Catlett, shows the humanity and the significance of blacks. As he has explained," If at times my productions do not express the conventionally beautiful, there is always an effort to express the universal beauty of man's continuous struggle to lift his social position and to add dimension to his spiritual being." 9 Lawrence concentrated on people. Lawrence consistently directed his historical themes to reflect the social conditions under which people of African ancestry had lived. His paintings show joy and despair, hope and vision all within a narrative format that expressed the history as well as the political and social problems of African America. ${ }^{10}$ Lawrence emphasized the humanity in the faces gathered around the legs of a street corner orator, in the sick and

\footnotetext{
${ }^{8}$ Ellen Harkins Wheat, "Jacob Lawrence and the Legacy of Harlem." Archives of American Art Journal 30, no. 1/4 (1990): 124.

${ }^{9}$ Wheat, "Jacob Lawrence and the Legacy of Harlem." 126.

${ }^{10}$ David C. Driskel, “Jacob Lawrence (1917 - 2000)." The Journal of Blacks in Higher Education, no. 29 (2000):
} 
injured waiting in the Harlem Hospital clinic, in the men seeking work, in step sitters, and neighborhood scenes"11

This skill is eloquently illustrated in Lawrence's To the Defense (1986) serigraph (Figure 5) This image was created as a fundraiser for the NAACP Legal Defense Fund (LDF) and a prime example of Lawrence's artistic acumen. To the Defense allows us to witness the work of LDF and the humanity of black clients they serve. It would have been easy to show an actual courtroom scene with the NAACP Lawyers arguing their case before a judge or the clients consulting with the LDF attorney in his office, but where is the humanity in that? Instead, Lawrence chooses to compose an image that captures the lawyer-client interaction prior to entering the courtroom to communicate the urgency and the tension.

We witness the LDF attorney ready for battle, arms filled with papers, pencil in hand, and by his body language depicts his earnest desire and strong intention to help the clients and then Lawrence presents the humble, hard-working clients. We know this by observing several elements from the bible on the bench beside them which shows they are religious people, to the father's hat positioned neatly on his lap as a sign of respect to the LDF, to the father's toolbox on the floor near him because the father has likely just left a job to make it to court, and because the tools are how he supports his family so he takes great care to keep them insight. Each family member is physically connected and

\footnotetext{
${ }^{11}$ Bearden and Henderson, A History of African American Artists, 296
} 
with the males on either side of the female, protecting her from harm in a sense which shows love and concern for each other.

Lawrence connects the attorney and the family with the simple gesture of eye contact; a symbol of trustworthiness much in the way that people distrust someone who cannot look them in the eye. And Lawrence drives home the significance and critical role of LDF within the black community by placing the subject outside of the courtroom. In the background, we see the chaos and feel the hostility of the courtroom and we are reminded that the average black person could not navigate or succeed in that hostile environment without the LDF. Two Rebels (Figure 6) reminds us that not much has changed from Lawrence's time until now between the police and the communities they are supposed to serve as we witness a black man, obviously incapacitated being carried away by two white police who most likely inflicted the injuries.

The community bears witness to the injustice being perpetrated by the police because we see the eye watching in the background. The police are also aware of the rising anger of the witnesses to their brutality and they look nervously around as they depart the area to most likely finish the job away from watchful eyes who bear witness and give testimony. It is worth noting that Two Rebels was the first print Lawrence ever produce, and he did so in the classic black and white style associated with early $20^{\text {th }}$ century printing techniques. The final Lawrence image in the exhibition, and also among the first prints produced by Lawrence, is titled Brotherhood for Peace (Figure 7). This image portrays unity among blacks and whites as it speaks to the idea of unity among all races and the hope for humanity Lawrence always found and portrayed in his subjects. 
The art of Jacob Lawrence illustrates the lifelong influence a community can have on an artist, and how that informs the artist creativity and aesthetic.

Two Rebels (1963) lithograph

Brotherhood for Peace (1967) color lithograph

To the Defense (1989) color lithograph

\section{Leroy Campbell (b. 1956)}

Leroy Campbell's paintings, infused with history, tie the past to the present in the practice of Sankofa, the understanding that you can't move forward until you receive the lessons of the past. The vulnerability of his art, his soul, his ability to tell a story through the use of acrylic, paper, tapestries, and organic materials, creates an opportunity for conversation, for something real, for the human connection that we are all desperately seeking. ${ }^{12}$ Laurie McCall, Paint Magazine.

Leroy Campbell was born in 1956 in Monk's Corner, South Carolina, surrounded by, and fully engulfed in the traditions and culture of the Gullah community. The Gullah/Geechee people descend from the enslaved Africans who built and sustained the lucrative rice plantations of the marshy coastlands and inland estuaries between the Cape Fear River in North Carolina and the St. John's River near Jacksonville, Florida, collectively called the "Lowcountry." The Gullah built and sustained the indigo and longstaple cotton farms of the seventy-nine off-shore barrier islands of Georgia and South

12 Laurie McCall, “About the Cover Artist” Pink Magazine \& Millen Publishing Group, LLC.
37 New Orleans Road, Hilton Head Island, SC 
Carolina. ${ }^{13}$ Campbell grew up in a household where it was commonly held that the success of the present generation was made possible by the efforts of past generations. "My father expected excellence from each and every one of us," Campbell recalls, "Discussions around the dinner table amounted to quizzes about our ancestors or what new information we had learned that day" (Campbell, 2015). The Gullah developed a culture in which African languages, cultures, and community life were preserved by the slaves who were brought to America to work the rice fields. The humid, low country climate that allowed the rice crops to thrive, proved too harsh for white farmers. "Fearing disease, many white planters left the Lowcountry during the rainy spring and summer months when fever ran rampant and they left their African rice drivers, or overseers, in charge of the plantations." 14 As a result, slaves in the low country were left to themselves and were able to nurture traditions and maintain their African culture unlike anywhere else in America. "There is strength in knowing your history because it empowers you and encourages you to be great, we have an obligation to our ancestors to remember them and to leave a legacy for the next generation" (Campbell, 2015).

After leaving the cultural cocoon of his low country community, Campbell settled into the urban sprawl of New York, where he quickly melded into the hustle and bustle of urban life. Campbell became part of the creative community in the city and would spend hours at Mount Morris and Fort Green parks in Brooklyn, or Central Park in Manhattan, collaborating, discussing, and creating art with other artists while watching and listening

\footnotetext{
${ }^{13} \mathrm{~J}$. Lorand Matory, "The Illusion of Isolation: The Gullah/Geechee's and the Political Economy of African Culture in the Americas." Comparative Studies in Society and History 50, no. 4 (2008): 952.

${ }^{14} \mathrm{http}: / /$ www.beaufortsc.org/guides/gullah-history
} 
to African music and dance performances. Primarily self-taught, Campbell maintained a love of history and cultural pride as he traversed the dense, diverse communities of New York. He embraced the city and its people who were themselves only one or two generations removed from the south thanks to the great migration. In a December 27, 2018 interview in New York Amsterdam News, Campbell recalled "I developed a community of friends who saw in me the energy, the same spirit that the Gullah, the grandmothers from my community could see. They encouraged me to do my art and go forward with it" (Campbell, 2021).

"I was in heaven walking the streets of Harlem, standing in the footsteps of the legendary artists of the Harlem Renaissance and I studied them all, but was particularly

enthralled by the layers and textures of collage art of Bearden." (Campbell, 2020) Campbell's art reflects our connection to history through the collage technique of incorporating historical figures, books, and articles into each composition so that the viewer reflects upon the image and engages with the content. On January 31, 2017, Campbell told the Charleston Post \& Courier "I came from humble beginnings but I've always been blessed to come from a community of having many mothers, many fathers, many families, and I lived in a time where teachers cared about how you learned and I lived at a time where the parents were the loudest voice for the young people," (“Charleston artist Leroy Campbell dedicates his piece 'Bible Study' to victims of Emanuel AME Church shooting"). He continued "I have an obligation to remind our people of our greatness and achievements, and to share with them words of inspiration to counter the negativity we are bombarded with" (Campbell, 2020). 
The medium that Campbell utilizes to communicate is collage and acrylic. He weaves a tapestry of texture and vibrant colors; he also incorporates found objects into his assemblages including vintage furniture, books, fabrics, and everyday objects to portray slices of life and culture. But you will not find bullets, bloody clothing, or other items that portray death and destruction in the art of Leroy Campbell. "We (black people) are bombarded with negative images and disparaging news about how bad our lives are. That is not our truth and that is not what I want to portray with my art. Now Is the Time (2021) (Figure 8) is Campbell's inspirational narrative that was created to bear witness to the social justice movement of 2020. Reflective of his desire to uplift and inspire the image presents a dual narrative.

On the one side are images depicting the social justice protest composed of acrylic collage cutouts of protesters marching in the streets carrying signs on one side and in the center sits a little boy reading a book. Books are on the floor around him and the shelves on the left side of the image and they are all books designed to nurture and instill a sense of pride and self-worth. As the protest are necessary, so is knowledge. The black child does not have the luxury of being guarded against injustice but must learn and understand how to function in a world that may seek his demise. He must be educated on how to be. Campbell focused on the protesters and let their signs tell the story, while also giving the viewer some additional readings in the forms of books. Some of the educational elements also are incorporated into Campbell's tribute to Vice President Kamala Harris in his We Got Your Back (2021) (Figure 9). We see the image of Harris, in her sorority colors and their signature pearls as she is flanked by black female icons. The title has a dual meaning 
because of the millions of Americans that voted for the Biden Harris ticket, but it also symbolizes the women in the image who came before her.

In his Black Love Series (2018) (Figure 10), Campbell confronts the notion of the roles of the male and female by depicting the male nurturing the female. Campbell is not concerned with the notion of masculinity and femininity and wants to show the love that has existed between black couples for decades. One of the major psychological traps preventing black males from actualizing their dreams is getting caught up in the web of dichotomous thinking that arises from polarities generated by living under white oppression: the inclusion/exclusion dilemma, acceptance versus rejection of mainstream norms and goals, gay versus straight, black versus white lifestyles, acquiescence versus assertive confrontation, macho toughness, and so on. ${ }^{15}$ This is important for Campbell because he grew up in a household with two parents contrary to the racist narrative of the single black mother on welfare, or the absentee father. Our children, our communities need to see black love in action and not some misconception of what it means to be the "man" of the house. So, she sits comfortably on the floor as her man does her hair and she is at ease with his care. He is attentive and compassionate in his care for her hair, a recognizable part of the black woman's daily routine, a ritual that has a long tradition in black households. And the scene is not lacking for Campbell's signature collage with its many teachable messages.

Finally, a signature element in the art of Leroy Campbell is that, except for the mouth, his subjects have no discernable facial features or expressions. No smiles, tears,

${ }^{15}$ C. P. Gause "Chapter 2: BLACK MASCULINITY." Counterpoints 337 (2008): 40. 
anger, or any other emotion are present in a Campbell painting because he wants that response to come from the viewer. "I don't give my subject eyes because I want the art to speak, not observe. My art is designed to speak to the viewer which is why their mouths are prominent" (Campbell, 2021). Each Campbell composition is saying something, giving information, documenting events, inspiring, witnessing, and testifying via newspaper articles, photographs, and quotes that tell a story to the viewer and inspire and uplift. They remind the viewer of the accomplishments of those who came before us, and the greatness within each of us.

Now Is the Time - (2021) Acrylic and collage on wood

We Have Your Back - (2021) Acrylic and collage on wood

Black Love Series - 20170 Acrylic and collage on canvas

\section{Woodrow Nash (b. 1948)}

Ceramic sculpture of proud dignified African figures to challenge stereotypes of African as savages, and to directly challenge the misrepresentation of what is beauty.

Woodrow Nash was born in 1948 in Akron, Ohio where he still resides. Nash considers himself to be the product of sanctified churches, 1950s television images, and black inner-city neighborhood schools where he ultimately immersed himself and excelled in art (https://woodrownashstudios.com/the-artist/). After working as a freelance artist in Akron for several years, Nash made the move to New York City where he obtained an associate degree in Commercial Art and went on to become a successful fashion and entertainment industry illustrator. Nash further refined his figurative and technical illustrative skills after returning to the Midwest, working at American Greeting 
Corporation and Goodyear Aerospace Corporation. "I perfected my artistic skills, but I knew there was more that I needed to do with my art, something that would honor my people."

Nash came of age in the black power era of the 60s and 70s, a tumultuous time in America and as blacks fought for civil rights on the streets. Akron was located a stone's throw from Cleveland, where Malcolm X gave his famous Ballot or Bullets speech in response to the ongoing oppression of blacks that sparked riots across the country and in Cleveland. "This social justice movement ain't nothing new because I've been here before. Back then the growing sense of black pride was incredible and inspirational from the songs to the speeches we (blacks) were finally hearing somebody tell us that black was beautiful and something to be proud of. I wanted my art to reflect that pride and show that beauty. "

Woodrow Nash, 2021

The art of Nash also confronts the deeply ingrained by-product of slavery and racism in America - the colorist discriminatory practice within the African-American community. Because blacks were taught that whiteness - white skin, thin lips, small noses, and straight hair - was not only the desired standard of beauty but of success as well. Colorism discrimination among blacks can be directly traced back to slavery, where the friction between the house-slave and the field-slave originated. Lighter-skinned slaves i.e., typically those with direct kinship ties to whites, were favored by slave owners and were predominantly given work as house slaves as opposed to field slaves. That position of working in the house dramatically increased the chance that lighter-skinned blacks 
would be literate and trained in a trade. ${ }^{16}$ During the post-slavery era at the start of the $20^{\text {th }}$ century as many black institutions including churches, fraternities and sororities were being established, there was a criterion for membership known as the Brown Paper Bag Test. The Test practically guaranteed membership for anyone with skin that was lighter than a brown paper bag. In what is among the most widely circulated and popular African-American folklore, the brown paper bag is believed to signify degrees of acceptance and inclusion (that is, if one is fairer than the brown paper bag). ${ }^{17}$

Kerr posits that even after slavery, blacks with lighter skin tone enjoyed substantial social, educational, and economic advantages over blacks with darker skin tone. Studies find that blacks with darker skin tone were sentenced to an average of eight additional months of prison time compared to blacks with lighter skin tone, even after taking their prior criminal records into account. Moreover, darker-skinned, more Afrocentric appearing black Americans are significantly more likely to face the death penalty than lighter-skinned African American. ${ }^{18}$ "During the Black Power movement of the sixties and seventies, the light-skinned brother' with the big afro always attracted the ladies. Even today, music videos feature women with mulattos (light complexion with long straight hair) to represent what is beauty (Nash, 2019). In distinction to this whitecentric beauty ideal, Nash's work offers unapologetic blackness reflected in each image

\footnotetext{
${ }^{16}$ Ellis P. Monk, "The Cost of Color: Skin Color, Discrimination, and Health Among African Americans." American Journal of Sociology,121, No. 2 (2015): 401

${ }^{17}$ Audrey Elisa Kerr, "The Brown Paper Bag Principle: Of Myth and the Motion of Colorism." American Journal of Folklore 118, No. 469 (2005): 272

${ }^{18}$ Ellis P. Monk, "The Cost of Color", 402
} 
characterized by bold colors, broad lips and noses, and an intentional absence of eyes as if to demand that the viewer see themselves within each piece. His work is a call to embrace the strength and beauty of their blackness.

At first glance, a Nash sculpture can intimidate and even overwhelm the viewer with the strength of its' blackness, and Nash will be the first to tell you that is exactly the point. Woodrow Nash has created a signature style, an "African Nouveau" trademark that's solely his own. While the images are African, in general, the concept is 15th century Benin with the graceful, slender proportions and long, undulating lines of 18th century Art Nouveau" (https://woodrownashstudios.com/the-artist/). Because blacks were taught to hate their African features (kinky hair, wide nostrils, and thick lips) because those features thoroughly distinguished them initially, from the white slave owners and after slavery from the idea of beauty presented by white media and institutions. The point of the art of Woodrow Nash is to directly challenge the misrepresentation of beauty. Nash reclaims the notion of beauty as it was for Africans, the beauty that was converted to a liability by the colonizers and replicated within the black community. Nash presents kings, queens, royalty, and rulers to reflect the strength and pride history ignored at best, and completely covered up at worst. Nash sculptures need not raise a fist in protest because they stand as a powerful testimony to the dignity and humanity that black people deserve. Whether adorned with West African Adinkra symbols as illustrated with Proud Beauty (2020) (Figures 15), or proudly displaying the art of the African headwrap shown with Zuri (Beautiful) (2020) (Figure 16) or simply capturing the physicality of the black male as with Okora (Man) (2019) (Figure, 17). Bold colors, natural hairstyles, and fullbody markings give testimony to the origins of the tattoo practice embraced by people of 
all ages and races. It is without question that Nash has forced America to behold the true beauty, strength, and pride of the African people, but he also bears witness of that beauty to blacks and challenges them to move beyond the divisive legacy of colorism in order to stop minimizing their ethnicity but to flaunt it proudly instead.

\section{Sherry Shine (b. 1965)}

Rich textures, vibrant patterns, intricate layering techniques, and assembled elements, meld together to creates stunning art quilts made of fine silks and vintage fabrics that pay tribute to the journey of the African in America "The assumption that enslaved Africans arrived on these shores with nothing of their own refers only to their lack of material possessions (because) these Africans brought with them wisdom, abilities, and certain skills, including the techniques of applique, piecing, and embroidery."19 These are the elements Sherry Shine incorporates into her art quilt making. Her quilts are an affirmation of the lives lived by black men and women during the repressive Jim Crow era. Whether working together on a farm, heading North in search of a better way of life, or traveling back South to visit relatives they left behind., Shine is interested in creating a more complete portrayal of blacks during an era when they were legally categorized as being only $3 / 5$ 's human. Shine intends to counter the stereotypical images that were preferred by whites designed to promote the idea of white superiority and blacks as inferior, downtrodden, and hopeless.

\footnotetext{
${ }^{19}$ Carolyn Mazloomi, Spirits of the Cloth: Contemporary African American Quilts (New York, NY: Clarkson Potter/Publishers, 1998) 12.
} 
For black lives to matter, so must our history; our experiences; and our ancestors. "I want us to remember those lives because we did not always have proof of lives lived." There is beauty reflected in the images of Sherry Shine along with an air of sophistication that serves to document the existence of communities and travelers, their determination, and their resiliency. Shine needs to show the elegance of back folks during the Great Migration because that was a historic point in the history of our people in this country and appearances were everything. She envisioned images of the people her parents described seeing when they were children. She also remembers the peoples she saw on her trips into the city on the weekends and to visit family friends and relatives in Harlem.

Shine was born in Valhalla, NY less than an hour from Manhattan. "I was raised by my great grandmother, grandmother, and aunt which is why I gravitate toward depicting women in positive images in my work. They were old school and dressing casually in public was something they just didn't do, which is why I use those vintage fabrics as my way of paying homage to them" (Shine, 2021). Shine's relatives migrated up from the Carolina's and her Journey Continues Together -75 (2021) (Figure 11) pays tribute to the women who raised her. The ladies are shown sitting on their suitcases, adorned in the fashion stylings of the time, with hats, gloves, jewelry, and poised.

Shine's artistic abilities were evident early in life, and she enhanced her eye for design, fabric selections, and color combination at The Fashion Institute of Technology in New York. She gravitates to rare, vintage fabrics and seeks to composes complex layers of fabric, with elements of found objects and symbols to send messages and tell stories. It did not matter what menial jobs people performed during the week - from maids and cooks, butlers and chauffeurs - they were going to look their best when they socialized, 
attended church, and especially when they traveled. Even when viewed as less-than Shine intends for the style of a people in oppressive circumstances to outshine the light in which history would like to portray them. Black people lived outside of the cotton fields, they existed beyond the role of butler and maid; they were doctors and lawyers, musicians and educators, and they were proud of their ability to earn a living, raise a family, and enjoy life even when everything was stacked against them. We owe it to them to bear witness to their lives and honor their memory and see them in all of their grandness.

Shine chose not to pursue a recognizable protest theme with her art "Several themes run through (this) protest tradition: the brutality of slavery and white supremacy; the abhorrence of the portrayal of Africa and Africans as uncivilized; the hypocrisy of American democracy; the horrors of lynching; the emasculation of black men; the maligning of the character of black women; the demonization of poor blacks." 20 The quilts of Sherry Shine present a counter-narrative reminiscent of the dignity Catlett incorporated into her subject with a simple black and white engraving. "For me, I had to keep working when George Floyd died, I thought about his daughter a lot I believe that's where Afternoon Stroll (2019) (Figure 12) came from. Those two women are guides for each other walking together- collaborating together - figuring it out. They stand for community/protection which she (Floyd's daughter) will need" (Shine, 2021).

Contemporary quilters speak to a myriad of social and political issues, but Shine took a different approach. Instead of a protest image, Shine chooses to highlight our royal heritage with We Have Always Been Royal (2021) (Figure 13). This image, inspired by

\footnotetext{
${ }^{20}$ Carolyn Mazloomi, Spirits of the Cloth, 92
} 
the popular Netflix series Bridgerton, shed light on Queen Charlotte, the British queen of African descent. World history ignores the presence of blacks in leadership roles so with this image Shine depicts an elegant, confident, woman of influence, not a servant. Her creative strategy during the social justice unrest of 2020 was to focus on the strength and determination of the ancestors who had survived through worse periods. "That was my grandparents traveling down South to visit relatives, or us heading up North from the Carolinas to a better life in the midst of government condoned racism. Our ancestors were not three-fifths human - they were fathers, mothers, daughters, and sons and they would not be denied their humanity." (Shine, 2020) This is beautifully illustrated with People in the Field (2020) (Figure 14). Here we see a couple working together in a field. As the husband works in the yard, the wife climbs a ladder to position a quilt that bears the Underground Railroad quilt symbol. They are no longer slaves, but they continue to recognize the journey and work of their ancestors (Shine-2020).

The social justice protests that resulted from the brutal murder of George Floyd in May of 2020 were profound and impactful because black and white Americans united to demand change in a way that had never happened before. A nation bore witness and protesters gave testimony for Floyd and others with signs that simply read I Can't Breathe. Shine is concerned with bearing witness to the existence of a people during the brutal Jim Crow era that would not have tolerated the protests or the unity we witnessed in 2020. "Inspired by their own rich personal experiences and celebrating the African American family's capacity for survival and renewal art quilts are a testament to our 
creativity, endurance, resilience, and triumph." 21 For Shine, quilt making is a therapeutic experience. "It relaxes me to select fabrics and compose an image that honors those who came before us - to give them the respect they were denied. My work may not always scream protest but believe me it's there in its own way" (Shine, 2020).

\section{Kevin A. Williams (b. 1965)}

Figurative compositions and historical references that honor the beauty and strength of Africans in America.

Born and raised on the Southside of Chicago, Kevin A. Williams is an artist whose aesthetic foundation was laid in the basement of his parent's home in the early 1970s. "My parents loved music, and always had the latest albums so when they purchased the latest Ohio Players album, my sister and I would sneak downstairs to sneak a peek at the latest illustration" (Williams 2020). They had to sneak because the Ohio Players were famous for their seductive album cover which featured color photographs of nude women with props that illustrated album titles including Honey, Fire, and Skin Tight. It was then that the fire was ignited within Williams to draw the human anatomy, and Williams refined his drawing technique by competing with friends to see who could draw their favorite comic book heroes the best. After that he transitioned to fashion magazine illustrations because with a mother and three sisters, there was no shortage of material to pull from. Williams thrived in his Southside neighborhood, surrounded by

\footnotetext{
${ }^{21}$ Carolyn Mazloomi, Spirits of the Cloth, 46
} 
friends that challenged him to be better, supported by teachers that recognized the talent he possessed, and nurtured by his parents.

After high school, Williams received scholarships from Parsons and The Art Students League of New York, and briefly attended the Art Institute of Chicago and Columbia College but eventually dropped out of both schools. "I didn't feel that they could teach me what I wanted to paint, and how I wanted to show black life and speak to black people so I was out" (Williams, 2021). He realized that he could not express his creativity through the constraints of formal education. He wanted to prove, mostly to his father, that he could succeed in his venture as an entrepreneurial artist but he knew formalist imagery would not speak to his generation, his community. Williams sought to create images that allowed him to give testimony that would be believed among urban blacks. Williams felt no one was speaking to his generation in a voice they would listen to. He became that voice and took the urban art market by storm starting with his image Taking Her Back more than 25 years ago, and he has continued to grow and evolve with his collectors. "I was in their college dorm rooms, now I'm in their media rooms, mancaves, and diva dens" (Williams, 2021).

The art of Kevin Williams is visually seductive and powerfully narrated which is representative of his artistic aspirations. "My goal is to inspire and enlighten all of humanity to the beauty and strength of my people," Williams explains "I desire to place blacks in positions of power during a time when they had everything but power" (Williams, 2017) There is evidence of his early exposure to the female form courtesy of the Ohio Players, but his respect for women remains ever-present. That can be attributed 
to being raised in a household with three sisters and a mom. Many of Williams' works pay tribute to the black female as illustrated in Stolen Queen (2015) (Figure 18) and Rise (2021) (Figure 19).

Williams composed Stolen Queen utilizing a striking composition of oppositional elements, the first of which is presented in the color pallet - a white background and a brown figure. "I have always admired the work of Charles White and the early master printmakers who achieved so much with a minimal color palette" (Williams 2016). With the title in mind, Williams introduces another oppositional element; she is royalty, a ruler of people being treated as chattel. And yet another oppositional element is the contrast between her petite stature and the heavy shackle and chain around her neck. Unlike other works by Williams that incorporate great detail and facial features, this image is sparse but effective in illustrating how much the colonizers disregarded the people of Africa in their quest for free labor. The viewer is left to contemplate her fate as well as the fate of her family, her people, her guards. Williams wants the viewer to see the travesty and absurdity of the act of enslaving human beings.

We see the same compositional pallet in Rise as Williams again presents the black post-slavery black female against a light background devoid of any discernable elements. She sits, nude, on top of a mountain that represents the myriad of injustices perpetrated against blacks in America since they were stolen from Africa. These include lynching's by the KKK, black-face minstrels, slave ships, and even the "door of no return," the door in Ghana through which Africans passed and were forced aboard slave ships, never to return. Williams incorporates a recognizable symbol most associated with Jean Michel Basquiat, the crown which floats above her head beckoning her to continue her upward 
trajectory to rise above all the injustices she has suffered. She has been the witness to all of these things and she remains to give testimony and remembrance to her ancestors and future generations. She is also a testament to the will and determination to survive.

Another area that Williams gravitates to are historical tributes to great black leaders, but he goes beyond simple portraiture, as illustrated with Dear John (Figure 20) his tribute to the late civil rights icon, Congressman John Lewis. At the center is Lewis on the Edmund Pettus Bridge, the site of the Bloody Sunday confrontation that forever placed Lewis at the forefront of the civil rights struggle. Williams positioned Lewis above the actual confrontation with the Alabama State Troopers and the peaceful protesters, seconds before the troopers began their assault. We see resolve on both sides as Lewis and other protesters stand their ground. The only evidence of the violent clash that ensued that day is a single drop of blood at the bottom center of the painting. At the top of the painting is the Presidential Medal of Freedom awarded to Lewis by President Barack Obama in 2018. One final element of this composition is Williams use of black and white paint splashes at the top and bottom of the image to symbolize black people rising up to resist white supremacy and racial oppression.

The artists included in this exhibition have created images that are relevant to this time in our nation's history. Their desire to portray black Americans in a positive light, and to honestly tell our stories is rooted in their experiences within the black community and their awareness of how American history and media outlets do not always reflect the truth of blacks in America. Using an aesthetic informed by the black community they have sought to bear witness to lives lived and to give testimony in honor of those lives to be shared with future generations. 


\section{REFERENCES}

Bearden, Romare. Harry Henderson. History of African American Artist: From 1792 to Present. New York, NY: Pantheon Books, 1993.

Cooks, Bridget. Exhibiting Blackness: African Americans and the American Art Museum. Amherst, MA:

University of Massachusetts Press, 2011.

Driskell, David C. “Jacob Lawrence (1917-2000).” The Journal of Blacks in Higher Education, No. 29 (2000): 32-33.

Fulton, B.K. “Kevin Williams’ Art Radiates with Skill \& Beauty.” Soul Visions Magazine, August 2019, https://soulvisionmagazine.com/kevin-williams-art-radiates-withskillbeauty/

Gause, C. P. "Chapter 2: BLACK MASCULINITY." Counterpoints, No. 337 (2008): 37-59.

Kerr, Audrey Elisa. "The Paper Bag Principle: Of the Myth and the Motion of Colorism."

The Journal of American Folklore 118, No. 469 (2005): 271-89.

Gouma-Peterson, Thalia. "Elizabeth Catlett: "The Power of Human Feeling and of Art"." Woman's Art Journal 4, No. 1 (1983): 48-56.

Matthews, Nadine. "Artist Leroy Campbell on the Importance of Art and Community” New York Amsterdam News 12/27/2018, http://amsterdamnews.com/news/2018/dec/27/artistleroycampbell-importance-art-and-community/

Matory, J. Lorand. "The Illusion of Isolation: The Gullah/Geechee's and the Political Economy of African Culture in the Americas." Comparative Studies in Society and History 50, no. 4 (2008): 949-80.

Mazloomi, Carolyn. "Spirits of the Cloth: Contemporary African American Quilts," Clarkson N. Potter/Publishers, New York, 1998

Monk, Ellis P. "The Cost of Color: Skin Color, Discrimination, and Health among African Americans." American Journal of Sociology 121, no. 2 (2015): 396-444.

Wheat, Ellen Harkins. "Jacob Lawrence and the Legacy of Harlem." Archives of American Art Journal 30, no. 1/4 (1990): 119-26. 


\section{APPENDICES}

\section{Exhibition List}

Elizabeth Catlett: $\quad$ Mother and Child, (Figure 1)

I Have Special Reservations (1948, Woodcut) (Figure 2)

Sharecropper Male (1945, Woodcut) (Figure 3)

Sharecropper Female (1970, Linoleum cut) (Figure 4)

Jacob Lawrence:

To The Defense (1986, serigraph) (Figure 5)

Two Rebels (1963, Lithograph) (Figure 6)

Brotherhood for Peace (1967, Color lithograph) (Figure 7)

Leroy Campbell: $\quad$ Now Is the Time (2021, Acrylic and collage) (Figure 8)

We Got Your Back (2021, Acrylic and collage) (Figure 9)

Black Love Series (2018, Acrylic and collage) (Figure 10)

Sherry Shine:

Journey Continues Together -75 (2021, stitched, appliqued, fused, sewn and painted art quilt) (Figure 11)

Afternoon Stroll (2020, stitched, appliqued, fused, sewn and painted art quilt) (Figure 12)

We've Always Been Royal (2020, stitched, appliqued, fused, sewn and painted art quilt) Figure 13)

The People in the Field (2020) (Figure 14) 


\title{
APPENDICES
}

\section{Exhibition List continued}

\author{
Woodrow Nash: $\quad$ Proud Beauty (2020) (Figures 15) \\ Zuri (Beautiful) (2020) (Figure 16) \\ Okora (Man) (2019) (Figure, 17)
}

Kevin A. Williams: Stolen Queen (2016) (Figure 18)

Rise (2020) (Figure 19)

Dear John (2019) (Figure 20 


\section{CURRICULUM VITAE}

NAME: $\quad$ Cathy B. Smith Shannon

ADDRESS: 18909 Ridgeleigh Lane

Louisville, Ky 40245

DOB: $\quad$ Louisville, KY - April 16, 1960

EDUCATION

\& TRAINING B.A. Communications

University of Louisville

$1979-1984$

PROFESSIONAL

SOCIETIES The Honor Society of Phi Kappa Phi 